\title{
Convergences et divergences : production orale, production écrite
}

\section{Evelyn Perry}

\section{CpenEdition}

\section{Journals}

Édition électronique

URL : http://journals.openedition.org/asp/3768

DOI : 10.4000/asp.3768

ISSN : 2108-6354

\section{Éditeur}

Groupe d'étude et de recherche en anglais de spécialité

\section{Édition imprimée}

Date de publication : 1 décembre 1995

Pagination : 163-174

ISSN : 1246-8185

\section{Référence électronique}

Evelyn Perry, «Convergences et divergences : production orale, production écrite », ASp [En ligne], 7-10 | 1995, mis en ligne le 24 septembre 2013, consulté le 19 avril 2019. URL : http:// journals.openedition.org/asp/3768; DOI : 10.4000/asp.3768

Ce document a été généré automatiquement le 19 avril 2019

Tous droits réservés 


\title{
Convergences et divergences: production orale, production écrite
}

\author{
Evelyn Perry
}

1 Convergences et divergences. C'est dans le cadre du thème retenu pour le XVI ${ }^{e}$ Congrès $\mathrm{du}$ GERAS que nous aborderons une analyse contrastive de la production écrite et orale chez l'apprenant d'anglais langue 2 .

2 Il est question ici d'un apprenant-type d'un niveau moyen-fort ou moyen-avancé. Il (ou elle) est inscrit soit en premier cycle Gestion et Économie Appliquée (GEA), soit en Magistère de gestion, à l'Université de Paris-Dauphine. Dans les deux cas, l'étudiant est censé suivre des cours d'anglais de spécialité.

3 Celui qui, préparant un DEUG en premier cycle GEA, choisit l'anglais comme langue vivante, suivra une heure et demie hebdomadaire de cours d'anglais, où lui sera proposé un mélange de langue parlée et de langue écrite. Il assistera également toutes les 2 semaines à une séance d'une heure d'entraînement à la compréhension auditive et à la production orale. Quant à l'étudiant inscrit en magistère de gestion, il fera obligatoirement de l'anglais pendant trois ans, au rythme de trois heures par semaine: une heure et demie d'anglais oral ; même chose pour l'écrit.

4 Notons que les capacités linguistiques de l'étudiant ne sont pas déterminantes pour l'admission ni en magistère de gestion ni en premier cycle GEA. Nous avons donc affaire, dans les deux cas, à une population hétérogène dont le niveau en anglais peut varier énormément d'un niveau assez faible à une très bonne maîtrise de la langue. Il nous arrive aussi, comme dans toutes les filières d'ailleurs, d'avoir quelques vrais bilingues. Pour l'étude présentée ici, nous avons sélectionné uniquement les étudiants d'un niveau moyen-avancé, écartant à la fois les plus faibles et les plus forts. 


\section{La production écrite}

Depuis cinq ans environ je m'intéresse à l'acquisition du vocabulaire et plus particulièrement à l'importance que peut y jouer la confusion phonologique. M'inspirant des études précédentes de Lennon (1991), Blaas (1982) et Laufer (1990), je me suis proposé de constituer un corpus d'erreurs lexicales afin de mieux comprendre le lexique mental de l'apprenant d'anglais langue vivante et d'élaborer des logiciels multimédias les mieux adaptés aux besoins ainsi repérés.

Dans un premier temps, pour aborder les problèmes lexicaux à l'écrit, j'ai analysé 44 copies d'examen fournies par des apprenants d'un niveau moyen-fort ou moyen-avancé. Ceux-ci étaient alors inscrits à Dauphine en Premier cycle GEA. Sur un corpus de 20.000 mots écrits, je me suis donné la tâche de répertorier toutes les erreurs lexicales et d'en établir une taxinomie. Celle-ci est représentée dans le tableau ci-dessous.

Figure 1. Erreurs lexicales commises à l'écrit

\begin{tabular}{|l|l|}
\hline 1- confusions L1/L2 & $43,2 \%$ \\
\hline dont erreurs d'« interlangue » & $4,1 \%$ \\
\hline 2- confusions phonologiques en L2 (synforms) & $14,4 \%$ \\
\hline 3- CLI (choix lexical inapproprié) & $18,5 \%$ \\
\hline 4- collocations, L2 & $20,2 \%$ \\
\hline 5- collocations, L1 & $2,4 \%$ \\
\hline 6- erreurs lexico-grammaticales (L2) & $1,2 \%$ \\
\hline
\end{tabular}

7 Pour une discussion approfondie des résultats de cette enquête, le lecteur peut consulter l'article publié dans les Actes du XIVe Colloque du GERAS (Perry, 1993). ${ }^{1}$ Notons ici l'influence importante de la langue maternelle dans les représentations inachevées des mots en anglais : $42,3 \%$ de toutes les erreurs lexicales examinées peuvent s'expliquer par un calque en langue cible à partir du français.

Rappelons aussi que le sigle CLI, choix lexical inapproprié, fait référence à un choix erroné d'une vraie lexie en anglais ne convenant pas au contexte dans lequel elle est employée. Exemple: Some countries are just outlined, and it will be hard to catch up with countries like France, Luxembourg or Denmark who fulfill the requirements for entry into the EMS, où il est impossible d'envisager l'insertion du mot outlined dans le contexte de la phrase citée. Il s'agit d'un choix lexical provenant éventuellement d'une confusion sémantique entre outlined et l'expression pushed to the sidelines. La sélection de cette lexie ne semble pas guidée par une confusion phonologique telle que : a ball in a China shop pour a bull in a China shop ou encore, menial work pour manual work. Quant aux termes qualifiés d'erreurs d'interlangue, il s'agit des mots logiquement possibles, tels que determinate pour determine , evoluate pour evolve, ne figurant pas dans les dictionnaires : lexies « inventées » par des apprenants. 


\section{La production orale} simulations interprétées s'inspirent de Supermarket Magic, un jeu de rôle tiré du livre sur la simulation de G. Porter-Ladousse, publié par Cambridge University Press. Alors que le jeu de rôle prévu dans le livre concerne sept personnages différents, nous avons mis quatre participants seulement par groupe, afin d'encourager une participation plus importante de chacun. Les étudiants ont eu pour tâche de simuler une réunion entre quatre personnages :

- le PDG d'une grande chaîne de supermarchés,

- le gérant d'un des supermarchés appartenant à cette société, situé dans la banlieue difficile, mais fictive, de Rington,

- le représentant d'une société vendant des produits antivol,

- le président d'une association de consommateurs.

Les quatre sont réunis pour discuter des solutions éventuelles à apporter au problème de vol croissant dans le supermarché de Rington. ${ }^{2}$

La cinquième simulation - il y en aura d'autres dans le corpus définitif - est une situation imaginée par les étudiants eux-mêmes. Il est question ici d'un scénario de rêve, où les anciens élèves du magistère s'expriment librement devant leurs anciens professeurs sur les défauts (et quelques rares qualités) du cursus imposé. Comme dans les autres simulations, il y a eu quatre participants. ${ }^{3}$

\section{Résultats de la deuxième enquête}

Sur les cinq séances, j'ai répertorié 187 erreurs lexicales. Lorsque nous observons les erreurs lexicales comptabilisées dans les deux tableaux ci-dessous, Figures 2 et 3, nous constatons tout d'abord une grande convergence des données entre l'écrit et l'oral. Nous y voyons de nouveau l'influence massive de la langue maternelle. En ce qui concerne les simulations, 40,2\% de toutes les erreurs lexicales commises peuvent s'expliquer par l'influence du français sur la langue cible; pour les exposés, ce chiffre est de $29,7 \%$. Si 
nous rajoutons les erreurs de collocations provenant d'une interférence de la langue maternelle, le pourcentage d'erreurs du type L1/L2 progresse respectivement de $40,2 \%$ à $52,4 \%$, et de $29,7 \%$ à $39,6 \%$.

Nous pouvons constater, en revanche, plusieurs divergences entre les performances attestées à l'écrit et à l'oral : le pourcentage d'erreurs de collocation s'expliquant par une confusion entre le français et l'anglais est beaucoup plus important dans les transcriptions de l'oral que dans le corpus d'erreurs commises à l'écrit. Inversement, le nombre d'erreurs de collocation commises à l'intérieur de la langue cible semble être en baisse.

Sur les 20000 mots examinés dans le corpus écrit, je n'ai trouvé aucun terme en français. Cependant, la tentation de prononcer quelques mots en langue maternelle ou de ne pas prendre le temps de chercher la traduction de certains termes techniques s'est manifestée à l'oral.

En ce qui concerne les confusions phonologiques s'expliquant par une représentation partielle ou inachevée de la langue cible - phénomène auquel je me suis beaucoup intéressée lors de la première enquête - elles se révèlent encore moins présentes dans mes transcriptions de l'anglais oral qu'elles ne l'étaient dans le corpus d'erreurs écrites. L'ensemble de ces informations paraît indiquer que les confusions phonologiques, bien qu'elles soient attestées chez les francophones parlant et écrivant l'anglais, ne constituent pas l'essentiel de leurs problèmes lexicaux en langue 2.

Autre divergence: très peu d'erreurs à l'oral du type "interlangue ", c'est-à-dire, les lexies à mi-chemin entre l'anglais et le français, dont il était question ci-dessus. À l'écrit, le pourcentage de cette catégorie d'erreur était très faible, de $4,7 \%$; à l'oral, il est pour ainsi dire, inexistant.

Figure 2. Erreurs lexicales : simulations

\begin{tabular}{|l|l|}
\hline 1) Confusions L1/L2 & $40,2 \%$ \\
\hline 2) confusions phonologiques & $10,9 \%$ \\
\hline 3) Choix Lexicaux Inappropriés & $13,4 \%$ \\
\hline 4) collocations, L2 & $7,3 \%$ \\
\hline 5) collocations, L1 & $12,1 \%$ \\
\hline 6) erreurs lexico-grammaticales & $12,2 \%$ \\
\hline
\end{tabular}

Figure 3. Erreurs lexicales : exposés

\begin{tabular}{|l|l|}
\hline 1) confusions L1/L2 & $29,7 \%$ \\
\hline 2) confusions phonologiques & $12,8 \%$ \\
\hline - confusions phonologiques (L1) & $5,9 \%$ \\
\hline
\end{tabular}




\begin{tabular}{|l|l|}
\hline 3) Choix Lexicaux Inappropriés & $10,8 \%$ \\
\hline 4) collocations, L2 & $9,9 \%$ \\
\hline 5) collocations, L1 & $9,9 \%$ \\
\hline 6) erreurs lexico-grammaticales & $17,3 \%$ \\
\hline 7) mots en français & $7,8 \%$ \\
\hline
\end{tabular}

21 Une remarque s'impose concernant la place des erreurs lexicales chez l'étudiant d'un niveau moyen-avancé: l'étude de Lennon et l'enquête de Blaas citées auparavant montrent que chez les apprenants d'un niveau avancé, les erreurs lexicales l'emportaient sur les erreurs morpho-syntaxiques. Jusqu'ici, dans notre étude des erreurs commises à l'oral, les erreurs morpho-syntaxiques sont presque aussi fréquentes que les erreurs lexicales, comme le démontrent les chiffres reportés sur les Tableaux 4, 5 et 6 ci-dessous. Si nous examinons les chiffres attestés pour les exposés (Figure 6), nous verrons que sur un total de 187 fautes. 101 (ou $54 \%$ ) étaient des erreurs lexicales; les erreurs morphosyntactiques s'élevant à 39,5\%; les problèmes stylistiques à 6,4 \%.

Examinons maintenant dans le détail les résultats obtenus pour les simulations (Figures 4 et 5). Dans le premier groupe (Figure 4), le nombre global d'erreurs lexicales était de 32 ; celui d'erreurs morpho-syntaxiques de 22. Quant au deuxième groupe (Figure 5), 37 erreurs lexicales sont attestées par rapport à 16 erreurs morpho-syntaxiques. L'analyse des transcriptions d'un troisième groupe, en revanche, a révélé $76 \%$ d'erreurs grammaticales par rapport à 22,5\% d'erreurs lexicales.

24 À l'intérieur de chaque groupe, il existe une grande variété d'erreurs attestées individuellement pour chaque apprenant. Il serait difficile d'établir un profil «type » pour ces apprenants et leurs performances à l'oral.

25 Nous sommes loin, ici, des résultats obtenus par Lennon (6\% seulement d'erreurs morpho-syntaxiques) et Blaas (trois fois plus d'erreurs lexicales que d'erreurs morphosyntaxiques). En outre, Lennon a repéré 468 erreurs seulement sur un corpus de 21.000 mots - c'est-à-dire que les erreurs représentent $2,2 \%$ du total des mots transcrits. Sur un échantillon de 3597 mots - les exposés sur thème libre -, nous avons répertorié 187 erreurs - ou $5,2 \%$ du corpus. Autrement dit, les sujets de Lennon et de Blaas, plus avancés que les apprenants participant à notre étude, font moins d'erreurs de tous types confondus que nos étudiants ; leur faible taux d'erreurs morpho-syntactiques par rapport à leurs collègues moins avancés nous laisse supposer que les compétences grammaticales en langue étrangère sont plus rapidement acquises que les compétences lexicales.

Les résultats de notre étude ne contredisent pas ceux de Blaas et de Lennon, au contraire. $\mathrm{Au}$ stade moyen-avancé d'apprentissage, les compétences grammaticales en anglais oral de nos participants ne dépassent pas de beaucoup les connaissances en matière de lexique. À une phase ultérieure, par contre, l'apprenant semble bien maitriser la grammaire, même s'il ne domine pas complètement le lexique.

Si les résultats auxquels nous sommes parvenus jusqu'ici dans le corpus oral diffèrent des données rassemblées par Lennon et Blaas, ils ressemblent davantage, en effet, aux chiffres rencontrés lors d'une expérience informelle à l'écrit pratiquée avec un groupe de 
21 étudiants - encore une fois d'un niveau moyen-avancé - en première année de premier cycle à Paris-Dauphine. Évaluant les fautes de grammaire, les erreurs lexicales et les erreurs stylistiques dans des dissertations rédigées dans les conditions d'examen, nous avons trouvé que, sur un total de 497 fautes, 53,3\% étaient d'origine lexicale. Les problèmes morpho-syntaxiques s'élevaient à 40,9 \% ; les erreurs stylistiques, à 5,9\%.

Figure 4. Simulation : groupe 1

\begin{tabular}{|l|l|l|l|l|}
\hline étudiant & lex. & gram. & styl. & mots \\
\hline$n^{\circ} 1$ & 12 & 5 & 1 & 293 \\
\hline$n^{\circ} 2$ & 4 & 1 & 2 & 103 \\
\hline$n^{\circ} 3$ & 9 & 8 & 0 & 173 \\
\hline$n^{\circ} 4$ & 7 & 8 & 1 & 142 \\
\hline Total & 32 & 22 & 4 & 711 \\
\hline
\end{tabular}

Figure 5. Simulation : groupe 2

\begin{tabular}{|l|l|l|l|l|}
\hline étudiant & lex. & gram. & styl. & mots \\
\hline$n^{\circ} 1$ & 3 & 2 & 0 & 87 \\
\hline$n^{\circ} 2$ & 12 & 8 & 0 & 293 \\
\hline$n^{\circ} 3$ & 14 & 2 & 0 & 367 \\
\hline$n^{\circ} 4$ & 8 & 4 & 0 & 236 \\
\hline Total & 37 & 16 & 0 & 962 \\
\hline
\end{tabular}

Figure 6. Production orale : 9 exposés

\begin{tabular}{|l|l|l|l|l|}
\hline exposé & lex. & gram. & styl. & mots \\
\hline$n^{\circ} 1$ & 5 & 6 & 1 & 157 \\
\hline$n^{\circ} 2$ & 19 & 9 & 1 & 516 \\
\hline$n^{\circ} 3$ & 13 & 5 & 1 & 319 \\
\hline$n^{\circ} 4$ & 11 & 10 & 1 & 452 \\
\hline$n^{\circ} 5$ & 26 & 22 & 2 & 1100 \\
\hline$n^{\circ} 6$ & 4 & 4 & 0 & 252 \\
\hline
\end{tabular}




\begin{tabular}{|l|l|l|l|l|}
\hline$n^{\circ} 7$ & 13 & 8 & 0 & 227 \\
\hline$n^{\circ} 8$ & 2 & 2 & 3 & 197 \\
\hline$n^{\circ} 9$ & 8 & 8 & 3 & 372 \\
\hline Total & 101 & 74 & 12 & 3597 \\
\hline
\end{tabular}

\section{Conclusion} moyen-avancé qui se dessine grâce à ses écrits ressemble beaucoup à son profil aperçu à l'oral. Ses compétences morpho-syntaxiques et lexicales sont - à quelques détails près en équilibre. Cet équilibre disparaîtra à un stade d'apprentissage supérieur où la maîtrise des structures grammaticales se verra dans le faible pourcentage d'erreurs morphosyntaxiques.

Ces premiers résultats sur les erreurs lexicales commises à l'oral sont fondés, pour l'instant, sur un échantillon très limité ; ils ne font que mettre en lumière quelques axes de recherche à poursuivre dans un avenir proche : la place de la confusion phonologique dans le lexique mental de l'apprenant non anglophone, l'importance relative de l'erreur lexicale par rapport à l'erreur morpho-syntaxique à des stades d'apprentissage différents, le rôle de la première langue dans le développement des capacités lexicales de l'apprenant en L2.

\section{BIBLIOGRAPHIE}

Blaas, L. 1982. « Fossilisation in the advanced learner's lexicon ». Manuscript non publié.

Department of English, University of Utrecht.

Dulay, H. C. and M. K. Burt. 1974. « Should we teach children syntax? ». Language Learning, 23, 245-58.

Dulay, H. C. and M. K. Burt. 1974. « Natural sequences in child language acquisition ». Language Learning 24, 37-53.

Ellis, R. 1986. Understanding Second Language Acquisition. Cambridge : Cambridge University Press.

Felix, S. 1978. « Some differences between first and second language acquisition ». In Waterson, N. et C. Snow (dir.), Development of Communication. New York : John Wiley and Sons.

Johansson, S. 1978. «Studies in error gravity. Native reactions to errors produced by Swedish learners of English ». Gothenburg Studies in English 44.

Laufer, B. 1990. « Sequence and order in the development of L2 lexis: some evidence from lexical confusions ». Applied Linguistics 11/3, 281-296. 
Lennon, P. 1991. « Error: Some problems of definition, identification, and distinction ». Applied Linguistics 12/2, 180-196.

Meara, P. 1987 [1983]. Vocabulary in a Second Language, volumes 1 \& 2. Londres : Centre for Information on Language Teaching and Research.

Perry, E. 1993. « Erreurs lexicales chez l'apprenant d'un niveau avancé ». ASp 2, 81-92.

Perry, E. 1994. « Production écrite, production orale : le lexique mental en L2 ». Les Cahiers de l'APLIUT 14/1, 28-47.

Porter, R. 1977. « A cross-sectional study of morpheme acquisition in first language learners ». Language Learning 27, 47-62.

Ravem, R. 1974. « The development of WH questions in first and second language learners ». In Richards, J.C. (dir.), Error Analysis. Londres : Longman.

Schumann, J.H. 1980 « The acquisition of English relative clauses by second language learners ». In Scarcella, R. et S. Krashen (dir.), Research in Second Language Acquisition. Rowley, MA : Newbury House.

\section{ANNEXES}

\section{Annexe 1}

Transcription, groupe 2 "Supermarket Magic" - Magistère de gestion, juin 1993

BRAND: Good afternoon. Thank you for coming today. I'm very pleased to meet you and uhhh...I have to speak, uhhh... we have all to speak about a very big problem with which our company is faced today...uhh...the ABC chain of supermarkets is faced with uhh...the problem of shoplifting especially in the Brighton branch... supermarket... so I would like to hear Mr. Jones as the manager of this branch.

JONES: Well, you know, the last past year I had been trying a few methods to stop shoplifting uh... and Mrs. Brand was agree uhh... with this test. First, I try uhh... a systematic uhh... serch... sear... searches of customers but the problem was that it was creating a bad image. So, I tried the security guard. But... uhh... it was eating up the profits. ..so it was a very big problem, and uhh... the third umm test I made was very intricate electronic surveillance equipment. But uhhh./. it was too expensive for us . But uhh...so you can see that none of these of these systems was really efficient. But in my opinion, we must find a ... solution, because everybody has interest in that. First, the supermarket, of course, because the shoplifting represents nearly $10 \%$ of the total sales, and it isn't bearable anymore. After, the consumer associations, because they pay shoplifting. You must know that the cost of shoplifting is included in the price you pay. And uhh... if it keep on rising, the prices will follow this raise. And ... uhh... it effect of course, the customers themselves because uhh.. I like them to be able to go to shop without fear to cope with shoplifters and not to be taken for a shoplifter. It has already happened, and it is uhh... a dramatic situation. Well... so, to conclude, [inaudible] Yes, yes, I think so. So to conclude, I am favorable to try - I don't say to adopt - but to try this new system... uhh... which is uhh...which is a system of the subliminal messages. [laughter] I don't know if it is an efficient method, but uhh...I think it would be a great thing to try it, so I'm going to give the floor to Mr. Uhh...to Mr. uhh.. 


\section{Stacy [plusieurs voix]}

Stacey that is going to speak about this method.

STACEY: OK...Uhh...Thank you Mr. JONES, uhh... first of all I would like to say that I'm very pleased to be here to explain you my product, and to present you what will be the next generation of uhh... anti-theft counter(?) theft security uhh... product in the supermarket area. First of all, I have to describe what the product is... Uhh... a subliminal message is uhh... recorded on a tape, and uhh...in order to discourage people from shoplifting. The consumer is not conscious The consumer does not hear the message, because the message is uncoded Uhh ... I gave you - in the brochure I gave you - you can lea, ...you can read the message from the Daily Gazette, uhh...which is a famous newspaper of the United States... you have an evidence in this uhh... magazine that .in uhm... the special area in Florida, mmm, uhhhhh... we had ten percent left (LESS) of theft in ten day, which is very short and within uhm an investment of ten thousand dollars, which is not so important compared to other systems. So, Uhhh..., we do not hire.(? have ?)...I'm very concerned of uhh... morality problems, and I can tell you that there will not be any other message on the tape. The only message you can hear, you don't hear it, in fact...

CA (Consumer Association): Could I interrupt you here, because my... first I have to present myself, uhm, I'm, uhm, the president of the national consumer association

STACEY: Nice to meet you

CA: We already know each other, and but what I think is that, in fact, I'm sure those subliminal messages, the cons the consumer is obviously manipulated, (it's manipulated? ) he doesn't know what's happening he's not conscious - it's what you said - and I think that this is a violation of their rights

BRAND: uhhh, yeah

CA: he's interfering with their liberty, that's not right

BRAND: OK, we'd like to hear more about the product

STACEY: if you want to speak of right(s), I can tell you that there is no law against sublim subliminal messages. So, there is no law, so we can do anything we want, BUT, but I said, we have our conscious, we...we're a customer too, and we don't want to violate the constitution, so I can tell you, I can assure you that we'll, we'll [...] we don't want to put some bad messages on the tape. We can set up a commission in order to hear all the messages and to to assure you that there will not be any other messages such like, messages like political messages or messages in order to sell more or anything like that. I can tell to Mr. uhhhh... Mr. Johnson and Mr. Brand that the music is designed to help people to buy. I mean, it's a good music, not rock, or something like that,

JONES: only country music

STACEY: only country music, what people like, like, love

CA: Can I just add something? I...I uh...understand what's your point, I... I'm willing to believe that your firm is highly ethical, or ethic? Ethic. And, uh, but how c how how could I trust any firm that enter in that market? I think that we should not make, uhh, first exper... that the first experience should not be made. It's going to uhh open the door to many other experiences which are not uhhh going to be uhh controlled or which are 
going to be unfair with uhhh customers in the shop, and moreover, there is something we don't know,. We don't know exactly all the effects of uh the subliminal messages on the minds of people. Maybe it's dangerous. We don't know. I don I don't want that people take the liberty to uhh... to put uhhhto uh... the mind of customers. I'm here to protect customers and I don't want that this could happen.

\section{Annexe 2}

Simulation, groupe 5 - Magistère de gestion, octobre 1992

IVAN: Well, I'd like to make a point. We were convinced into joining your uh joining your uh cursus, by the opportunity we saw to have good studies with professional uh aid. But for some of us, this (fantastic) opportunity masqueraded into uh less of time. So, my point is to comment on that problem we feel

MARIE: What are you doing now? Do you work? Do you uhm...

IVAN: Yes, I'm searching, I'm searching for, I'm looking [laughs at his mistake] for a job, and it's quite hard to find. Well so, we're in to comment about this point, first about the studies - they were supposed to be good - and second about the professional aims which are not fulfilled... as... we are all work... uh looking for a job

MARIE: How do you know? How do you know? You're looking or a job and you don't have a ...

STEPHANE: I have a job, and uhhh I think it's not uhh I didn't get it because of the Magister and uh spending time in this company, I found, I found that the Magister didn't give me the skill to uh...

MARIE: Which skill would you like to have?

STEPHANE: ...[inaudible] I ...to speak about this, about the study and...

ALEX: OK, maybe I could say something. Thank you for coming uh today. I'm pleased to see you since uh you you you have uh been away from the Magistère de gestion de Dauphine. And uh I think it's good thing to to speak about these uh problems but for me they are not problems and if you want to see Well, you're telling me that you didn't find uhmmm, the the the skills you you need for professional life and I I I will say that you're the first persons that came to me and asked asked tell me and told me this. It's a surprise for me, you know. And, uh, secondly, if you were not uhhh happy of these Magister, I'm asking myself why have you not stopped the Magistère after two years and why did you spend one more year if it wasn't if it wasn't the uh good the uh good....

STEPHANE: We are wondering...We are wondering.

ALEX: So why didn't you do another third cycle?

STEPHANE: Because, because we need a first cycle diploma and uh because of the way the Magister is built up it's not possible to get a third cycle because we couldn't do another cursus and since we only have our Maîtrise in September because of uh some kind of notation problem, you know that uh you only give us, gave us our copies back in September, and not in June, as you should have done, we couldn't uh apply for a third cycle diploma. So, we had to finish our Magister.

MARIE: OK, so what are things, you think it's not good in the Magister? Which one and why and can uh...? 
STEPHANE: Uhm...

IVAN: If you don't mind, I would just like to make a point...Yes, uh, I'm going to answer your question. First, uh...yes, we did learn something, we did learn many tricks or practical skills.

STEPHANE: That's right...

IVAN: We cannot say the opposite, but...in such huge time and with such huge means, financial means, we could have done much better during these three years. AND that's the first point. And uh this relates to the skill of a number of teachers that are not so good and this refers also to the spirit of the Magister, which is not as [inaudible]

MARIE: Have you, have you ever been in a business school?

STEPHANE: No, no ... [inaudible]... the Magister...

MARIE: OK, the lecturers are nearly the same.

STEPHANE: I, I don't mind.../ IVAN: No, No ...

MARIE: OK, So we are, you are the Magistère de gestion. What is the Magistère de gestion? It's a program uh just uh comment dit-on parallèle?

TEACHER: parallel

MARIE: parallel on the university, and it's like a little business school. You have the same type of programme that you have in a in a real business school and if you didn't want to have this kind of lectures and this kind of lessons, I mean uh...

STEPHANE: Let's take an example...

\section{NOTES}

1. Le niveau avancé dont il est question dans cet article est défini en termes de notes obtenues à un examen écrit d'anglais de spécialité. Les apprenants, étudiants en Premier cycle GEA, ne sont pas des spécialistes en langue. Dans ce contexte, un véritable niveau avancé est très rare : il s'agit plutôt d'un niveau First Certificate ou moyen-avancé.

2. Voir transcription, Annexe 2.

3. Voir transcription, Annexe 2.

\section{RÉSUMÉS}

Dans un premier temps, nous examinons un corpus de 20000 mots écrits en anglais L2 afin de déterminer une taxinomie d'erreurs lexicales commises par des apprenants d'un niveau moyenavancé. Ces productions font ensuite l'objet d'une analyse contrastive juxtaposant les six catégories d'erreurs lexicales répertoriées à l'écrit aux erreurs commises à l'oral par d'autres étudiants du même niveau. 
A 20,000 word corpus of written English is examined in order to draw up a taxonomy of lexical errors attested for upper-intermediate learners of English. The six lexical error types found in the written corpus are then compared to errors occurring in transcripts of spoken English produced by other upper-intermediate level learners.

INDEX

Mots-clés : acquisition lexicale, confusion phonologique, erreur, interlangue, production écrite, production orale

Keywords : error, interlanguage, oral production, phonological confusion, vocabulary acquisition, written production

\section{AUTEUR}

\section{EVELYN PERRY}

Evelyn Perry enseigne à l'IUFM de Paris. 